\title{
In Pursuit of a Different Revolution: Russian Populists of the Seventies Generation in 1917
}

\author{
Ben Eklof and Tatiana Saburova
}

For many today "populism” is a fraught term, conjuring up images of demagogy and authoritarianism; by contrast the Populist movement in Russia that commanded the allegiance of much of the population during 1917 could hardly have been more different than its current namesake. Despite the fact that recent western scholarship has focused mainly on its link to terrorism, Russian populism was in fact extraordinarily diverse and intellectually fertile but shared broadly democratic convictions, an egalitarian drive for social justice, an anti-capitalist stance, support for the cooperative movement, and a belief in the potential of the peasant commune. ${ }^{1}$ The Socialist Revolutionary Party, with up to a million members, was an "umbrella organization" that did not seek to impose doctrinal uniformity-something which was both a strength and a weakness in 1917. ${ }^{2}$ The much smaller People's Socialist Party

The authors express their gratitude to the anonymous reviewer whose insightful critique and generous disagreement with parts of our argument forced us to rethink and clarify our position. Tatiana Saburova worked on this article within a framework of the Basic Research Program at the National Research University Higher School of Economics (HSE) and was supported by a subsidy granted to the HSE by the Government of the Russian Federation for the implementation of the Global Competitiveness Program.

1. Susan K. Morrissey, "Terrorism, Modernity, and the Question of Origins," Kritika: Explorations in Russian and Eurasian History 12, no. 1 (Winter 2011): 213-26; Claudia Verhoeven, The Odd Man Karakozov: Imperial Russia, Modernity and the Birth of Terrorism (Ithaca, 2009); Lynn Ellen Patyk, "Remembering 'The Terrorism': Sergei Stepniak-Kravchinskii's Underground Russia," Slavic Review 68, no. 4 (Winter 2009): 758-81; Anna Geifman, Thou Shalt Kill: Revolutionary Terrorism in Russia, 1894-1917 (Princeton, 1993). On early Populist ideology (up to 1881) see Andrzej Walicki, A History of Russian Thought from the Enlightenment to Marxism (Stanford, 1979), 222-67. There is an enormous literature on Russian Populism; foundational works include, aside from Franco Venturi, Roots of Revolution: A History of the Populist and Socialist Movements in Nineteenth Century Russia (New York, 1960), see Boris Samuilovich Itenberg, Dvizhenie revoliutsionnogo narodnichestva: Narodnicheskie kruzhki $i$ "khozhdenie v narod" v 70-kh godax XIX v. (Moscow, 1965); Nikolai Alekseevich Troitskii, Pervye iz blestiashchei pleiady: Bol'shoe obshchestvo propagandy 1871-1874 (Saratov, 1991). For the wave of interest in Populism in the 1960's and 1970's, see Philip Pomper, The Russian Revolutionary Intelligentsia, 2nd ed. (Wheeling, 1993 [1970]), and especially on the Chaikovskii Circle: Reginald Zelnik, "Populists and Workers: The First Encounter between Populist Students and Industrial Workers in St. Petersburg, 1871-74," Soviet Studies 24, no. 2 (1972): 251-69, and Martin A. Miller, "Ideological Conflicts in Russian Populism: The Revolutionary Manifestoes of the Chaikovsky Circle, 1869-1874," Slavic Review 29, no. 1 (Spring 1970): 1-21. For surveys of Soviet-era Russian-language historiography see Nikolai Troitskii, Russkoe revoliutsionnoe narodnichestvo 1870-kh godov: Posobie k spetskursu dlia studentov istoricheskogo fakul'teta (Saratov, 2003). For an early study of non-revolutionary Populism, see Richard Wortman, The Crisis of Russian Populism (Cambridge, Eng., 1967); for the period immediately following 1881, see Derek Offord, The Russian Revolutionary Movement in the 1880s (Cambridge, Eng., 1986).

2. For a survey of the activities of the SRs in 1917 and a note on historiography see the two articles by Michael Melancon: "The Socialist Revolutionary Party (SRs), 1917-1920" and "The Left Socialist Revolutionaries, 1917-1918," in Edward Acton, Vladimir Cherniaev, and William Rosenberg, eds, Critical Companion to the Russian Revolution, 1914-1921 (Bloomington, 1997), 267-80, 281-90. 
at its peak had no more than eleven thousand members. ${ }^{3}$ It was emphatically gradualist, rejected class warfare and compulsory expropriation of noble landholdings without compensation, and acknowledged the necessity of a strong state (gosudarstvennost') to implement change and mediate between the country's various interests. ${ }^{4}$ It emphasized the need to educate the peasantry before it could participate "consciously" in politics, and hoped to utilize a democratized zemstvo to pursue its goal of social, cultural and political transformation. ${ }^{5}$

Russian populism was also multi-generational. Generational history does not yet have a robust presence in histories of 1917, yet without it one is hard pressed to understand the actions in that year of an older cohort of prominent revolutionaries such as Vera Figner or Nikolai Chaikovskii, those who partook in the populist movement from its inception to the assassination of Alexander II in 1881 and thought of themselves as the "seventies generation." ${ }^{6}$ This essay focuses upon two such individuals: Figner herself, a legendary member of the People's Will who turned to terrorism after 1878, and Nikolai Charushin, a second-tier figure and member of the earlier Chaikovskii circle who rejected that means of struggle. ${ }^{7}$ Each spent roughly two decades incarcerated or in exile

3. In Russian known as the NS Party, in June 1917 it joined up with the Trudoviki, becoming the Trudovaia Narodno-Sotsialisticheskaia Partiia.

4. For more detail on the activities and platform of the NS Party, both after 1906 and during the 1917 Revolution, from which most of this information is drawn, see the essay by Galina Sergeevna Anonpieva and Nikolai Dmitrievich Erofeev in N.D. Erofeev, ed., Politicheskie partii Rossii: Konets XIX - pervaia tret' XX veka. Entsiklopediia (Moscow, 1996), 619-26; Alla Viktorovna Sypchenko, Narodno-sotsialisticheskaia partiia $v$ 1907-1917 gg. (Moscow, 1999). Short biographical sketches of NS Party members as well as documentation can be found in Alla Viktorovna Sypchenko, ed., Trudovaia narodnosotsialisticheskaia Partiia: Dokumenty i materialy (Moscow, 2003).

5. Vasilii Vasil'evich Zverev, N. I. Kanishcheva, and Andrei Nikolaevich Medushevskii, Modeli obshchestvennogo pereustroistva Rossii. 20 vek (Moscow, 2004), 43-462; Trudovaia narodno-sotsialisticheskaia Partiia, 64-71.

6 . The usage of the term "generation" has prompted much discussion surrounding the works of Karl Mannheim, Pierre Nora, and others. Should it be used to denote a symbolic community linked by common ideas and values, one which experienced shared historical events, or an age cohort? For the question of how generational identity applies to Russian society see: Iurii Levada and Teodor Shanin, eds., Pokolencheskii analiz sovremennoi Rossii (Moscow, 2005); Stephen Lovell, "From Genealogy to Generation: The Birth of Cohort Thinking in Russia," Kritika: Explorations in Russian and Eurasian History 9, no. 3 (Summer 2008): 567-94. Deploying the generational approach to populism allows us to identify the seventies generation as a symbolic community, one that took shape under influence of the literature of the 1860s, and the philosophical theories of anarchism, evolution, subjective sociology, participation in organizations from the Chaikovskii circle to the People's Will. Those who experienced these times began to apply the label "seventies generation" in the early twentieth century in order to distinguish themselves from neoPopulists. The seventies generation became a memory site in the memoirs of participants in the revolutionary movement and became fixed in the bio-bibliographical dictionary project of the late 1920s. It is noteworthy that in the early years this cohort called themselves "social revolutionaries"; the term "populist" was affixed to them later by others.

7. Tat'iana Saburova and Ben Eklof, Druzhba, sem' ia, revoliutsiia: Nikolai Charushin i pokolenie narodnikov 1870-kh godov (Moscow, 2016). Despite his relative obscurity, Charushin's footprint was not insignificant: his memoirs $O$ dalekom proshlom, 3 vols. (Moscow, 1926-1931; the first volume was reprinted in 1973) are oft-cited in histories of 
before their release and return to society at the turn of the century. After the Bolshevik triumph, each chose to remain in Russia but in an uneasy relationship with the Soviet authorities and in rather close collaboration with each other. ${ }^{8}$

While we focus on these two, they were by no means the only ones of their cohort who participated energetically in the revolution. ${ }^{9}$ Their emphasis upon "ethical rationalism" reflected positions adhered to throughout lives filled with adversity and refined by two decades of full-blooded immersion in provincial life, civic activities, journalism, and oppositional politics after release from exile near the turn of the century-something largely overlooked by historians. The norms and principles that had been agreed upon in the 1870s had not allowed them to stand to the side as events unfolded; as Alexander Pribylev, a member of the People's Will and then the SR Party, wrote about his decision to assume responsibility for agricultural affairs in the Ural region for the Provisional Government: "I didn't feel I had the right to turn down that obligation."10 Likewise, Charushin later recalled that despite strong reservations he felt morally obliged to accede to persistent entreaties of his peers and join a Supreme Soviet organized to resist the Bolsheviks. ${ }^{11}$

Recent accounts of Russia's home front in 1917 pay little heed to this cohort of elderly revolutionaries, who in fact played a considerable role in events, especially in the provinces where they were sprinkled about in various moderate groupings, including the Mensheviks, the SR and NS parties, and even the Kadets. ${ }^{12}$ In 1917, despite their small numbers, the impact of this older generation - both by reputation and by their actions-was not inconsiderable; also in the provinces where they served as a bridge between parties. When they appear in the narrative it is as "losers," however, hapless members of a hapless intelligentsia working in a dysfunctional Provisional Government and unable to take decisive action. Examining their responses to the evolving situation in the context of their previous life experiences allows us to better understand what motivated them, how they reasoned and made sense of events, and why they insisted on the efficacy of local, small-scale change and gradualism over polarization, rupture, and violence.

the populist movement. The newspaper he founded served as a major source for a well-regarded recent history of daily life in 1917: Igor' Vladimirovich Narskii, Zhizn' v katastrofe: Budni naseleniia Urala v 1917-1922 (Moscow, 2001).

8. Saburova and Eklof, Druzhba, sem' ia, revoliutsiia, 347-90.

9. Despite the assertion of one former populist that advanced age and poor health had prevented her generation from participating in events and instead forcing them to stand aside as observers, and despite the silences and omissions in their memoirs brought out in no small degree by the notorious trials of 1922 against the SRs, we find affirmation of their involvement (see, for example, Iu. Iu. Figatner, ed., Deiateli SSSR i revoliutsionnogo dvizheniia v Rossii: Entsiklopedicheskii slovar' Granat, (Moscow, 1989), 49-50, 56-57, 108, 133, 139, 172-73, 186, 195, 221, 225, 253-54, 284, 295, 336).

10. Ibid., 195.

11. Ibid., 295.

12. Sarah Badcock, Liudmila G. Novikova, and Aaron B. Retish eds., Russia's Home Front in War and Revolution, 1914-1922. Book 1: Russia's Revolution in Regional Perspective (Bloomington, 2015). 
It would be rash indeed to generalize from the experience of two individuals, or even from that of their generation or of the Populist movement in its entirety. The seventies generation was held together more by an ethical code than by a program. Its ties were forged at an early stage of adulthood in circumstances of isolation from the larger society and active persecution by the state, which in turn led to long years of incarceration and exile. In contrast, for many of a later generation, their beliefs and actions had been shaped while still immersed in the larger society. Later generations of neo-populists included many thousands whose preparation for life and personal ties came from their university years and professional training rather than prison and whose aspirations were largely for legal change; their personal bonds were much less intense. ${ }^{13}$ Some joined political parties, others did not, but all subscribed to the basic tenets of "populism."

Yet these generations freely mingled. Moreover, the seventies generation's experience after exile-a period about which their memoirs are largely silent-brought them much closer to the next generation of populists with its large cohort of professionals engaged in the cooperative and zemstvo movements. ${ }^{14}$ When in 1895 Nikolai Charushin returned from exile to his homeland in Viatka, his house soon became a meeting place for exiles regardless of age or party affiliation. While employed by the zemstvo or working at the newspaper he founded, he was joined in his efforts by activists ten or twenty years younger than him. Others of his cohort who took up similar enterprises in Siberia or European Russia experienced the same blending of generations, all the while maintaining their horizontal ties in an extensive network of former populist exiles across the entirety of the empire.

In 1926, Figner reflected upon the events of 1917: "We had waited so long for this moment but strange as it seems I didn't experience unbridled joy; instead I was made uneasy by a mix of happiness, sadness, and anxiety. Everything had come about too easily and too fast." ${ }^{15}$ Nevertheless, throughout the year she actively engaged in public affairs, organizing a shipment of books to peasants in her native Kazan', taking part in demonstrations for women's rights, participating in a Democratic conference and Pre-parliament. ${ }^{16}$

13. Il'ia Gerasimov, Modernism and Public Reform in Late Imperial Russia: Rural Professionals and Self-Organization, 1905-30 (Basingstoke, 2009).

14. Populists most likely ignored this period because they felt it necessary in the climate of the 1920s to focus on the heroic period of their lives in order to defend their legacy as revolutionaries. In the third volume of her memoirs Figner divided her past into two periods: "All that was outside the norms of ordinary existence: revolutionary activity, incarceration, exile to the far north and excruciatingly difficult isolation-all of this was now in the past. When this ended so did the "extraordinary" phase and what began can be labelled "the ordinary." Did it make any sense to continue to write about all that which stayed within the boundaries of the quotidian?" (Vera Figner, Izbrannye proizvedeniia $v$ trekh tomakh, 3 vols. [Moscow, 1933], 3: 9.)

15. Deiateli SSSR i revoliutsionnogo dvizheniia v Rossii, 253.

16. Rossiiskii gosudarstvennyi arkhiv literatury i iskusstva (RGALI), fond (f.) 1185, opis' (op.) 1, delo (d.) 230, list (1.) 7 (Letter from Vera Figner to Lidia Kupriianova, dated July 24, 1917). For Figner's activities in 1917 see Lynn Anne Hartnett, The Defiant Life of Vera Figner: Surviving the Revolution (Bloomington, 2014), 205-35. 
In March, Figner wrote a friend: "I am hopeful for a positive outcome and for freedom to win out." ${ }^{17}$ As the year passed, however, her trepidation mounted and she wrote on September 21: "Everyone is fed up with empty phrases and inaction as we tie ourselves up in knots, hopelessly obsessing about our differences. Only the Bolsheviks have managed to float like flotsam and jetsam in the sea of turmoil with their unbridled and unfulfillable promises to the benighted masses. ..."18 Ultimately she was to confess after reading Sukhanov's epic day-by-day account of the events of that turbulent year: "I came to the uncomfortable realization just how little I had understood about the course of the revolution at the time, just how myopic, unreflective, and politically unprepared I was. ...."19

Charushin, speaking on September 20, 1917 to delegates at the Third Provincial Peasant Congress in Viatka, recalled his emotions at an earlier date: "Naturally, like others I was happy, but that happiness was short-lived. Almost from the start of the revolution I experienced overwhelming anxiety." 20 Yet Charushin also immersed himself in activities. Throughout that year, he seemed to be everywhere-he was prominent in the Peasant Union and on the executive committee of the Viatka Peasant Congress, which convened on three occasions that year; he was elected a delegate to the reformed zemstvo, served on the food supply commission and later on the Supreme Soviet formed to resist a Bolshevik takeover after October that year. The newspaper which he had founded in 1905, Viatskaia rech' (VR), was a main source of information on events local and national during those turbulent times and documented developments in the countryside as the food situation deteriorated, peasants went hungry, discontent mounted, and episodes of violence affected his likeminded acquaintances. ${ }^{21}$ Like Figner, Charushin blamed Bolshevik agitators for the assault upon zemstvo and Provisional Government officials and made it clear he believed that their activities were beyond the pale. As early as April $27^{\text {th }}$, VR warned against the preaching of Lenin, arguing that he was sowing the seeds of anarchy and civil war. ${ }^{22}$

A believer in the potential of a moderate socialist coalition, Charushin placed his faith in a democratized local self-government and above all in the forthcoming elections to the Constituent Assembly. On October 27, reacting to the events in Petrograd, Charushin addressed the newly assembled zemstvo:

17. RGALI, f. 1185, op. 1, d. 231, 1. 89 (Letter from Vera Figner to Natalia Kupriianova, dated March 14, 1917).

18. RGALI, f. 1185, op. 1, d. 231, 1. 115-115 ob (Letter from Vera Figner to Natalia Kupriianova, dated September 21, 1917).

19. Ibid, dated July 15, 1923, 1. 141. Nikolai Nikolaevich Sukhanov, Zapiski o revoliutsii: $V$ trekh tomakh, 3 vols. (Moscow, 1991).

20. Viatskaia rech', (hereafter VR) September 22, 1917, 3. The work of Oleg Znamenskii also modifies the conventional narrative by describing considerable anxiety and trepidation among the intelligentsia of Petrograd as events on the streets unfolded in late February and March. (Intelligentsiia nakanune velikogo Oktiabria: Fevral'-oktiabr' $1917 \mathrm{~g}$. (Leningrad, 1988), 32-42, 51-58, 73.)

21. A complete list of such items can be found in the unpublished index of VR held at the Herzen Regional Library (Kirov): Gali Chudova, Ukazatel' soderzhaniia gazety "Viatskaia Rech'”1908-1917, 10 vols. (Kirov, 1975), Vol. 9, items 1029-68, 1083-94.

22. VR, April 25, 1917, 2. 
"That which we fearfully anticipated has indeed happened. In Petrograd a civil war has been declared. On top of the ongoing collapse at the front and in the rear we now have more calamity. I believe we share the blame with the old regime for this terrible situation, for we devoted ourselves exclusively to intensifying the revolution, and we intensified (ugubliali) it until we arrived at Bolshevism." ${ }^{23}$ In her autobiography, Figner also wrote: "I recognized that we, revolutionaries of an earlier generation, had engendered the current conditions, and when I heard complaints I responded: 'didn't we ourselves call for social revolution in (18)73-4?"'24

Yet, after conceding that the very political movement to which he had devoted his own life may have contributed to the chaos now descending upon Russia, Charushin urged his compatriots to regroup. "I think this is the end point-we can go no further and we will turn back in the opposite direction. I am sure that for the majority their urge for a functioning government (gosudarstvennost') will resurface and bring the country together. After a few days or weeks this crisis will pass. After all, not all of Russia is infected with Bolshevism."25

It was not to be. Misfortune was the bitter pill Charushin and his friends had to swallow; to be arrested by revolutionaries, many of whom had themselves suffered under the tsarist regime and who had seemed to be comrades in arms. Incarcerated four times between 1917 and 1919, at one point he wrote his interrogators: “. . . at the same time that the Soviet authorities are acknowledging the debt they owe to those who gave their lives in the cause of freedom, offering up every manner of commemoration to my comrades in the revolutionary struggle, even planning to build monuments to (Sofia) Perovskaia, (Andrei) Zheliabov and others, at the same time [those] who remain among the living and merit the same treatment can in fact find no place in the Soviet socialist republic except the prison!"26

Populists strove, but why were their efforts ultimately in vain? Certainly these elderly revolutionaries-while having proven their mettle by decades of incarceration and exile-were programmatically ill-prepared to deal with an increasingly polarized, anarchic, and violent society in the midst of total war. Their hostility to the Bolsheviks was visceral, and they lacked the components William Rosenberg identified as key to the latter's success: "A capacity for organization, an ideological clarity, and a social positioning that facilitated affiliation with the radical relocation of power and authority."27

Populists like Charushin are roundly criticized for unduly placing their hopes upon the zemstvo, which since the turn of the century had been a place of employment for many. Yet many of them had suffered dismissal and often

23. Gosudarstvennyi arkhiv Kirovskoi oblasti (GAKO), f. 616, op. 1, d. 267, 1. 66.

24. Deiateli SSSR i revoliutsionnogo dvizheniia v Rossii, 254.

25. GAKO, f. 616, op. 1, d. 267, 1. 69; VR, October 29, 1917, 2.

26. Gosudarstvennyi arkhiv sotsial'no-politicheskoi istorii Kirovskoi oblasti (GASPIKO), f. SU 6799, (Revolutionary Tribunal) op. 4, d. 4577, 11. 22-23 об. (letter dated Nov. 14, 1918).

27. Edward Acton, Vladimir Cherniaev, and William G. Rosenberg, eds., Critical Companion to the Russian Revolution 1914-1921 (Bloomington, 1997), 29-30. 
exile during the "righting of the zemstvo" in the aftermath of 1905 and were well aware of its shortcomings. The 1908 Narodno-Sotsialisticheskaia (NS) party program placed high hopes upon transforming the countryside through that institution, but only once it had been fundamentally democratized and dedicated were populists in the majority at the zemstvo. In 1917 the Provisional Government also leaned heavily upon that institution, but the effort to legally overhaul it, introduce volost' level units, and carry out elections took time, and it was late summer or early fall before the "renewed" zemstvos began to function..$^{28}$ Until then familiar representatives of the old order continued to hold key positions and historians have found abundant examples of peasant hostility to the zemstvo as a remnant of the old order.

Certainly the delays in introducing a democratized zemstvo cost the Provisional Government dearly, even if-at least in Viatka-such delays were not entirely its fault. But a look at the journals of the reformed provincial assembly once it actually convened on October 24 casts matters in a somewhat different light. It is poignant to read the transcripts of this session and the following one in December, in which this group of some eighty or so delegates struggled to ward off the Bolshevik onslaught, while at the same time addressing the urgent need to provide food and fuel for the city, to help keep factories in operation, to keep essential services running, to subsidize a free press, and to collect taxes in order to address such concerns. Even more striking was the attention given to schools: their determination to prioritize educational reform at a time of crisis can be understood only if we note that they regarded it as the key to producing an informed electorate, without which no democracy could thrive. ${ }^{29}$

Populists are often denigrated for being out of touch with the peasantry but such accusations are simply not true. Charushin's experiences with the peasantry (1895-1908) through the zemstvo were in many ways typical for his generation. Returning from exile to his native Viatka, he had taken up employment as a fire insurance agent and after 1905 served as the authorized representative of the All-Zemstvo Famine Relief Organization. Responsible for organizing famine relief in that huge province, he set up district committees and managed to maintain soup kitchens, provide school breakfasts, dispense flour to families, and establish mobile medical teams, but was also criticized for misuse of resources and confessed the difficulty of obtaining reliable information about household wealth-not least because the governor had forced the closure of the zemstvo statistical board and was carrying out mass

28. Iurii N. Timkin, "Demokraticheskaia vlast' i viatskoe obshchestvo v 1917 godu," in Vlast' i obshchestvo: Istoriia i sovremennost' (Kirov, 1998), 75-76.

29. GAKO, f. 616 (the provincial zemstvo uprava), op.1, d. 267, 1l. 7, 45-53, 70-71, 98-102, 106-108. Historians have also been discovering instances of peasants turning to the zemstvo for aid in 1917-actions that were after all less likely to be seen as newsworthy and therefore to leave behind documentation in the periodical press. See Liudmila Novikova, “Zemstvo, State and Peasants in Arkhangel'sk Province,” 1917-20,” in Russia's Home Front, 87-108. A comprehensive history of the zemstvo, both before and during the revolution, remains to be written. A useful start in this direction can be found in the work of Nadezhda Nikolaevna Kabytova, Vlast' i obschestvo $v$ rossiiskoi provintsii: 1917 god $v$ Povolzh'e (Samara, 1999), 126-43. 
arrests of zemstvo professionals who were also serving as members of the famine relief committees. ${ }^{30}$ In 1906, Vera Figner had also obtained resources to distribute to suffering villagers in her native Kazan', but was quickly overwhelmed by petitioners and distraught by her inability to determine true need. In both cases they were forced to practice triage and distribute largesse in a frustrating effort to distinguish genuine need from the entreaties of a wily subaltern population practiced in deception when engaged with their "betters." 31

Charushin's experience promoting fire prevention measures was of a different nature. Part of a large scale campaign to transform how villages situated their households, it involved providing loans for fire resistant roofs, organizing fire-fighting brigades, and rearranging the settlement patterns of entire villages to avoid clustering. Dispensing famine relief put Figner in the "unsupportable role of a "barynia" and Charushin as a classical "plenipotentiary outsider." 32 The fire insurance program involved drawing up and enforcing contracts for loans, a task to which Charushin devoted himself for over a decade, and for which he won commendations from a politically conservative district zemstvo. This was an entirely different way-transactional-of interacting with the peasantry. Contracts, transactions, cost effectiveness, negotiations, and enforcement-this is not the stuff of a romance with the peasantry. ${ }^{33}$

As ghost editor of VR, Charushin had maintained contact with a network of rural correspondents and covered in detail the tribulations of an impoverished peasantry suffering abuse from local officials. Likewise, in the 1870s Figner had applied her medical training in villages in Samara and Voronezh, and had gained the trust and respect of villagers. Combined with her later experience, she had seen both the good and the bad. In short, both had gained an intimate familiarity with village life and had a clear grasp of the mentality of the peasantry. ${ }^{34}$

Drawing upon the tenets of post-colonial scholarship, some excellent historians have also labelled the populist emphasis upon educating the peasantry paternalistic, part of a project of "making peasants backwards." 35

30. Saburova and Eklof, Druzhba, Sem'ia, Revoliutsiia, 241-48.

31. See Cathy A. Frierson, All Russia is Burning! A Cultural History of Fire and Arson in Late Imperial Russia (Seattle, 2002).

32. Figner, Izbrannye proizvedeniia, 3:97-128, esp. 103-4; F. J. Bailey, "The Peasant View of the Bad Life," in Theodor Shanin, ed., Peasants and Peasant Societies (Hammondsworth, 1971), 302-5.

33. Like Charushin, Peshekhonov, a member of the NS Party and Minister of Food Supply in the Provisional Government, had considerable experience of peasant economic life in Voronezh province and wrote extensively on the topic based upon his hands-on research. See Ol'ga L'vovna Protasova, A.V. Peshekhonov: Chelovek i epokha (Moscow, 2004).

34. Figner, Zapechatlennyi trud: Vospominania v 2 tomakh, 2 vols. (Moscow, 1964):1, 152-74; Charushin was also active in the Viatka zemstvo's renowned program to produce and distribute affordable books for the peasantry-a sustained effort which required frequent surveys to discern popular tastes and reading preferences in order to keep the project financially afloat (Saburova and Eklof, Druzhba, sem' ia, revoliutsiia, 231-41; 264-65).

35. Yanni Kotsonis, Making Peasants Backward: Agricultural Cooperatives and the Agrarian Question in Russia, 1861-1914 (New York, 1999); Aaron B. Retish, Russia’s 
Charushin's speeches and the pages of VR in 1917 certainly are sprinkled with phrases revealing what some would see as a patronizing discourse about the peasantry. Such terms as "benighted," "ignorant," "misled," and "mob violence" would seem to confirm that. He was surely alarmed at the kind of outbursts of rage levelled at his own friends among the professional intelligentsia.

Yet simply put, as Richard Wolin has observed, indiscriminately labeling such efforts to uplift subaltern populations as part of a "predatory and imperious mission civilisatrice" is reductionist. ${ }^{36}$ Painting the populists and zemstvo employees as blinded by their own "self-referentiality" does them a disservice. ${ }^{37}$ In this case it oversimplifies what was in fact a complex, shifting, and multi-dimensional relationship that had emerged, especially since the 1890s. Many of the 75,000 or so professionals (not including another 150,000 teachers) working in the villages by 1914 had endured many years of hardship and penury. ${ }^{38}$ They had lived cheek by jowl with the peasantry, working to relieve poverty, eliminate contagious diseases, combat exploitation, and expand education.

Thus, it seems truly misplaced to dismiss with a wave of the hand as paternalistic or even "inherently tyrannical" the lifelong work of Charushin, his cohorts, and the succeeding generation inspired by similar ideals. ${ }^{39}$ Their project was in reality one of emancipation rather than hegemony. After all, populists always insisted that any genuine social transformation could take place only if it was affected by and not only for the peasantry, and if the state had itself gained a popular mandate through a Constituent Assembly. Looking back, Figner wrote: "A period of parliamentary freedom seemed to me to be essential for the political and civic education of the masses. ${ }^{40}$ At the time, Charushin was especially aggrieved when the left SR faction which had gained control of the Peasant Congress in Viatka sought to monopolize the flow of information to the countryside. He lamented: "Don't lose track of the fact, my fellow citizens, that until only recently the village had been closed to any free exchanges of opinion. So now it is being educated and led in one direction alone by a single party line." ${ }^{41}$

Peasants in Revolution and Civil War: Citizenship, Identity, and the Creation of the Soviet State, 1914-1922 (Cambridge, Eng., 2008).

36. Richard Wolin, “'Modernity': The Peregrinations of a Contested Historiographical Concept," American Historical Review 116, no. 3 (June 2011): 741-51. In that article the author skeptically examines the post-modernist discourse on colonialism and hegemonic relationships with subaltern populations. The quotations are his but aptly describe the approach taken by scholars such as Retish and Kotsonis.

37. Ibid., 742. It is another matter whether or not they were willing to recognize humanity's baser and more predatory instincts. Their understanding of modernity certainly differed from that described by Daniel Beer in Renovating Russia: The Human Sciences and the Fate of Liberal Modernity, 1880-1930 (Ithaca, 2008), according to which the impact of criminology, psychiatry, and sociology had provided much of the Russian intelligentsia with a more pessimistic view of human nature. Instead, the seventies generation retained the optimism of the "neo-Enlightenment" era of the Great Reforms.

38. Peter Waldron, Governing Tsarist Russia (New York, 2007), 110.

39. Wolin, "Modernity," 744.

40. Deiateli SSSR i revoliutsionnogo dvizheniia v Rossii, 254.

41. Charushin could have added, as another delegate did, that the Congress itself, and the Soviet of Peasant Deputies, was kept afloat only by large subsidies from the zemstvo 
Finally, the argument that hostility to the intelligentsia was nearly universal is also problematic. Aaron Retish argues that in Viatka "by autumn, peasants' political acumen had ripened and they no longer showed... patience with educated society's political tutelage." ${ }^{42}$ Yet Scott Seregny and Ilya Gerasimov have demonstrated the lasting ties that had been established by the outbreak of World War I between many teachers, agronomists, and the peasantry. ${ }^{43}$ More recently, some historians have also noted the mass departure of professionals from the countryside in the summer of 1917 in order to participate in national electoral politics and to carry out administrative tasks for a Provisional Government extremely short of skilled personnel. ${ }^{44}$ It was a bitterly ironic twist of fate-those who could have provided a link with the countryside were removed from the scene when most needed.

One can justifiably point out the inability of Charushin and other moderate socialists to address the growing polarization that was the order of the day, and agree that resting their hopes largely on a Constituent Assembly led to passivity that contrasted strikingly with the audacious moves of a party promising land, peace, workers' control, and self determination to a desperate population-a program it was soon to abandon.

But was it wholly unrealistic for Charushin and Figner to place their hopes upon the Constituent Assembly? The growing consensus of historians is that the "dual power" established in Petrograd bore little resemblance to the "kaleidoscope" of arrangements that prevailed elsewhere in the country, and that even as late as October the Bolsheviks did not enjoy broad support in many areas outside the capital city. ${ }^{45}$ Charushin viewed matters from the perspective of Viatka and could hope only to help shape events in that enormous province. By the autumn of 1917 the situation there was certainly unsettled, but an informal coalition of moderate socialists still held sway. From that vantage point it was not unreasonable to hope that the gathering scheduled for January 5 could produce a mandate legitimizing the agenda most parties on the left supported, and halt the drift towards anarchy and civil war. Eventually, only the intervention of forces sent from the center tipped the balance. ${ }^{46}$

and local subsidies, was unable to pay its dues to the national organization, and had received only paltry financial support from local branches, many of which were still functioning as units of the Peasant Union. VR, September 22, 1917, 4.

42. Retish, Russia's Peasants in Revolution and Civil War, 6, 9, 99, 112-13, 128-29.

43. On this topic see Scott J. Seregny, "Zemstvos, Peasants, and Citizenship: The Russian Adult Education Movement and World War I," Slavic Review 59, no. 2 (Summer 2000): 290-315; Kotsonis, Making Peasants Backward; Ilya Gerasimov, "On the Limitations of a Discursive Analysis of 'Experts and Peasants' (An Attempt at the Internationalization of a Discussion in Kritika)," Jarhrbucher fur Geschichte Osteuropas 52, no. 2 (2004): 261-73.

44. Sarah Badcock, Politics and the People in Revolutionary Russia: A Provincial History (Cambridge, Eng., 2007), 101, 121.

45. Sarah Badcock, "Structures and Practices of Power: 1917 in Nizhegorod and Kazan' Provinces," in Russia's Home Front, 357.

46. See Donald J. Raleigh, "Echoes of the International across the Historiographies," in Russia's Home Front in War and Revolution, 1914-1922, 387. As Timkin has argued, had events in the country as a whole moved in a different direction, or had Viatka been left on 
As one local historian insisted during the memory wars of the perestroika era, Charushin may or may not have been prescient in describing the Bolsheviks as “'a plague,' a bacchanalia (of violence) launched against the peasantry, a mockery of the historical past, a sullying of democracy offering no guarantee of a person's dignity or even life." ${ }^{\prime 47}$ But it is wrong to accuse his generation of detachment from reality, naiveté, or incomprehension, for he and his friends knew the Russian peasant well and had considerable practical experience in the relationship between state and society. At the very least we can argue for their generation, as another historian writing about the members of NS Party recently put it: "That the revolution took a different turn was their misfortune, not their fault." 48

its own to sort out its affairs, no Bolshevik victory would have been likely. Iurii N. Timkin, Smutnoe vremia na Viatke: Obshchestvenno-politicheskoe razvitie Viatskoi gubernii vesnoi 1917-osen’iu 1918 gg. (Kirov, 1998), 29, 39, 82-83.

47. Valentin Sergeev, "S kompetentnost' iu i bez neterpimosti (k sporam o N.A. Charushine)," in M. S. Sudovikov, ed., Kraevedenie v razvitii provintsial'noi kul'tury Rossii: Materialy 2-i Nauhcnoi konferentsii (Kirov, 2009), 271.

48. Zverev, et al., Modeli obshchestvennogo pereustroistva Rossii, 459. 